\title{
PARTISIPASI MASYARAKAT DALAM PEMILU SERENTAK TAHUN 2019 DI KABUPATEN BULELENG
}

\author{
Gede Kamajaya \\ Prodi Sosiologi \\ Fakultas Ilmu Sosial dan Ilmu Politik, Universitas Udayana \\ kamajaya_1965@yahoo.com
}

\begin{abstract}
ABSTRAK
Pemilu serentak pertama kali dilaksanakan di Indonesia di tahun 2019. Pemilu ini dilaksanakan untuk memilih presiden sekaligus seluruh legislative dari kabupaten hingga provinsi. Pemilu yang dilaksanakan sebelumnya dengan metode terpisah dianggap menelan biaya yang sangat besar sehingga dilakukan judicial review atas UU Pemilu. Sebagai implementasi atas asas vox dey vox populi dalam praktik demokrasi sebagai sistem politik, maka keterlibatan publik di dalamnya menjadi sangat penting. Keterlibatan public yang paling sering kita temui dalam praktik demokrasi umumnya berbentuk keterlibatan langsung dengan datang ke TPS untuk memberikan hak suaranya. Penelitian ini bertujuan mengetahui sejauh mana tingkat partisipasi masyarakat Buleleng pada pemilu serentak tahun 2019. Untuk mendapatkan hasil yang hendak dicapai sebagaimana tujuan tersebut di atas, penelitian ini menggunakan metode kualitatif dengan menghimpun data dari wawancara hingga studi dokumen. Hasil penelitian ini menunjukkan pengguna hak pilih di Kabupaten Buleleng sejumlah 439.787 jiwa, Secara prosentase, partisipasi masyarakat dalam pemilu serentak di Kabupaten Buleleng sejumlah 73,91\%. Pada pemilu serentak tahun 2019, ada 596.589 orang pemilih di Buleleng. Sementara jumlah pengguna hak pilih mencapai 439.787 orang yang terbagi ke dalam 2.146 TPS. Tingginya angka partisipasi disebabkan oleh keberhasilan sosialisasi KPU, informasi yang masif di media. Dari semua kabupaten yang ada di Bali, Buleleng tercatat sebagai salah satu kabupaten dengan tingkat suara tidak sah cukup tinggi yaitu sejumlah 37.449 sedangkan suara sah sejumlah 401.818. Tingginya angka suara tidak sah disebabkan persoalan teknis yang menyulitkan terutama bagi lansia. Berdasarkan hasil data yang dirilis KPU Bali, jumlah lansia di Buleleng menyentuh angka 92.101 jiwa.
\end{abstract}

Kata kunci: Kabupaten Buleleng, Partisipasi masyarakat, Pemilu, Komunikasi Politik

\section{ABSTRACT}

The 2019 election is the first simultaneous election in Indonesia. In addition to electing the president and vice president, the 2019 election also elects members of the DPR RI, DPD, Provincial DPR, and City Regency DPRD. The 2019 simultaneous elections were implemented after previously there was a lawsuit against Law No. 42 of 2008. One of the most important things in a democratic climate is public participation in the policy-making process and political process. One form of public participation in the policy-making process and political process is the involvement of citizens in the election process. This study aims to determine the extent of the participation of the Buleleng people in the 2019 simultaneous elections. To obtain the results to be achieved as mentioned above, this study uses a qualitative method by collecting data from interviews to document studies. The results of this study indicate that the number of users of the right to vote in Buleleng Regency is 439,787 people. In percentage terms, public participation in simultaneous elections in Buleleng Regency is $73.91 \%$. In the 2019 simultaneous elections, there were 596,589 voters in Buleleng. Meanwhile, the number of voting rights users reached 439,787 people who were divided into 2,146 polling stations. The high participation rate is due to the success of KPU socialization, massive information in the media. Of all 
the regencies in Bali, Buleleng was recorded as one of the districts with a fairly high invalid vote rate of 37,449 while the number of valid votes was 401,818. The high number of invalid votes is due to technical difficulties, especially for the elderly. In Buleleng Regency itself, the elderly voter rate is the highest compared to other districts and cities with a total of 92,101 with the number of male voters is 42,170 and the number of female voters is 49,931.

Keywords: Buleleng Regency, Public Participation, Election, Political Communication

\section{PENDAHULUAN}

Pada abad ke-14, Eropa mengalami fase sejarah yang sangat menentukan perkembangan kemajuan ilmu pengetahuan dan teknologi yang bisa kita temui hingga sekarang setelah sebelumnya mengalami fase abad kegelapan dimana ilmu pengetahuan tidak berkembang karena didominasi dimensi agama. Fase penting ini kemudian dikenal dengan abad pencerahan. Abad pencerahan ini mengusung liberalism berpikir yang entu saja berbeda dengan praktik yang ada di abad kegelapan. Pada masa pencerahan inilah apa yang sudah berkembang sebelumnya di Yunanai sebagai salah satu peradaban besar mulai dari filsafat, seni, arsitektur, music hingga berbagai teori politik kembali dikembangkan, dibaca dan disebarluaskan. (Kenzu,2017). Liberalism berpikir di era pencerahan ini berdampak pada banyak sisi, tidak hanya praktik politik namun juga ilmu pengetahuan dan teknologi. Berbagai temua yang dihasilkan dalam periode ini semisal mesin cetak mempermudah berbagai teori dan pengetahuan baru tersebar ke seluruh dunia.

Mengutip pemikiran Hutintong (2012), hingga hari ini demokrasi berhasil menjadi salah satu ideology politik yang tetap eksis pasca perang dunia ke-2. Ini terbukti dari bergesernya berbagai ideology dunia yang pernah dianut sebelumnya perlahan hilang dan digantikan demokrasi. Jerman misalkan, dengan system politik fasis yang dikomandoi Adolf Hitler pasca perang duania ke-2 kemudian menganut system politik demokrasi. Amerika sebagai salah satu negara pemenang perang berperan penting menyebarkan niali-nilai demokrasi keseluruh dunia melalui berbagai kebijakan ekonomi politiknya. Francis Fukuyama menyebut periode ini dengan lebih gambling bahwa, alternative ideologi politik selain demokrasi sudah terkubur dan yang hanya demokrasi yang bertahan (Fukuyama, 2004: 115, Giddens, 2009: 29). Factual perbedaan nama demokrasi yang dianut oleh berbagai negara di dunia, namun demikian pada prinsipnya demokrasi memiliki beberapa syarat utama mulai dari kompetisi menyoal kekuasaan, partisipasi sebagai pengejewantahan dari vox dey vox populi, dan jaminan atas hak masyarakat sipil. Untuk memenuhi syarat utama inilah pemilu menjadi pembuktian pelaksanaan jalannya kekuasaan karena lewat pemilulah kompetisi, keterlibatan public dan pemberian jaminan pada warga sipil tumbuh berkembang sekaligus mendapatkan legitimasi oleh rakyat (Marijan, 2012:83). Inilah garis pembatas yang tegas yang membedakan demokrasi dengan ideologi politik lainnya. 
Tahun 1955 adala pemilu pertama kali yang dilaksanan di Indonesia. Pemilu pertama kali ini menghasilkan parlement pertama kali di Indonesia mengingat situasi politik kala itu belum stabil disebabkan berbagai hal mulai dari eksternal hingga internal. Yang paling menghambat jalannya demokrasi di Indonesia kal itu tentu saja kolonialisme Belanda. Pasca berakhirnya era Orde Lama dan Era Orde Baru digantikan Era Reformasi, demokrasi elektoral menemukan momentumnya setelah sebelumnya negara cukup refresif membatasi jalannya perpolitikan dengan berbagai aturan salah satunya melalaui UU Normalisasi Kehidupan Kampus, UU Anti Mogok Kerja dan lainnya, sehingga lebih cenderung praktik demokrasi di era Orde Baru bercorak otoriter yang tidak memberi ruang pada lawan politik atau partai politik berdiri dan berkembang. Berbagai partai politik yang berlandasakan berbagai ideology di Era Orde Lama dipaksa menyatu dengan ideology tunggal pancasila sehingga praksis hanya menyisakan tiga partai politik yang merepresentasikan kelompok agama melalaui partai PPP, kelas bawah harus melalaui PDI dan golongan karya atau Golkar hal ini terjadi karena pemerintah Orde Baru mengganggap ketidaksabilan ekonomi di Era Orde Lama disebabkan oleh ketidaksabilan politik karena banyaknya partai politik.

Berbeda dengan era Orde baru yang sangat refresif menjalankan pemerintahan, Era Reformasi memberi ruang tumbuh kembangnya kebebasan sipil. Ini terbukti dari kembalinya system multi partai dalam pemilu pasca kejatihan Soeharto. Namun demikian pemilu yang dilaksanakan secara terpisah untuk memilih DPD, DPR RI, Provinsi, Kabupaten Kota hingga kepala dengan multi partai dianggap menghabiskan banyak biaya. Kondisi inilah yang kemudian menjadi dasar gugatan atas terhadap UU No 42 Tahun 2008 Tentang Pemilihan Presiden ke Mahkamah Konstitusi. Judicial review atas UU Pemilu di Mahkamah Konstitusi kemudian dikabulkan sehingga membawa konsekuensi perubahan pada system pemilu yang sebelumnya terpisah kemudian dilaksanakan secara serentak untuk memilih legislatif, dan eksekutif.

Perubahan system politik pasca Orde Baru di Indonesia selain bisa kita lihat melalui sistem multi partai juga nampak dari bagaimana keterlibatan publik dalam perumusan kebijakan public dan proses politik berdemokrasi. Keterlibatan publik dalam proses politik yang paling nyata dapat kita lihat setiap lima tahun adalah keterlibatan public dalam proses pemilu. Menyitir pemikiran Robert Dahl (Marijan, 2012) partisipasi adalah syarat dasar dari praktik demokrasi. Lebih lanjut Dahl menjelaskan, partisipasi dalam konteks ini adalah keterlibatan warga dalam pemilu untuk memilih pemimpin yang mereka kehendaki.

Komisi Pemilihan Umum Provinsi Bali mencatat pada tahun 2019 keterlibatan warga dalam pemilu menyentuh angka di atas $90 \%$ melampaui partisipasi nasional yang hanya sampai pada angka 77,5\%. Secara keseluruhan KPU Bali mencatat jumlah DPT di Bali tahun 2019 menyentuh angka 3.220.479 jiwa. Secara lebih rinci angka tersebut terbagi ke dalam 1.596.740 pemilih laki dan 1.623 .739 pemilih perempuan. Jumlah daftar pemilih dan tingkat partisipasi tiap kabupaten di Bali beragam dengan 
berbagai sebab yang melatar belakangi. Di Kabupaten Buleleng sendiri daftar pemilih tercatat sejumlah 596.5.89 jiwa dengan perincian laki-laki 298.894, perempuan sebanyak 298.030 jiwa dengan jumlah TPS terbanyak yaitu 2.146 buah. Buleleng sendiri sebagaimana tercatat dalam rekapitulasi suara KPU Bali adalah kabupaten dengan jumlah surat suara yang cukup tinggi dibanding kabupaten lain di Bali.

Tujuan dari penelitian ini selain mengetahui tingkat partisipasi pemilu 2019 di Kabupaten Buleleng, juga mengetahui jumlah surat suara tidak sah dan penyebabnya. Sehinnga dengan demikian. Hal ini penting dilakukan sebagai bahan evaluasi pelaksanaan pemilu serentak berikutnya sehingga bisa menjadi dasar untuk meningkatkan partisipasi masyarakat di pemilu-pemilu selanjutnya.

\section{TEORI PARTISIPASI POLITIK}

Tolak ukur utama sebuah negara berdemokrasi adalah seberapa besar masyarakat terlibat dalam setiap pengambilan keputusan dan keterlibatan public dalam urusan-urusan plitik lainnya. Karena itu, demokrasi secara sederhana, dapat juga diartikan sebagai keterlibatan public di dalam merumuskan suatu kebijakan yang berlaku pada jangka waktu tertentu secara periodik. keturutsertaan inilah yang kemudian dikenal dengan istilah "partisipasi". Partisipasi, berarti mengambil bagian/peranan dalam sebuah kegiatan/aktivitas. Dalam ranah politik tentu saja partisipasi berada pada ruang lingkup negara atau aktivitas pemerintahan dan hiruk pikuk politik lainnya. Dengan demikian, sejatinya baik partisipasi dan Demokrasi ibarat dua sisi mata uang yang tidak terpisahkan. Peran masyarakat dijamin dalam demokrasi karena peran tersebutlah yang menghidupi dan menjadi nafas jalannya demokrasi. Dengan kata lain, tidak akan pernah ada demokrasi tanpa partisipasi atau sebaliknya.

Keterlibatan public dalam demokrasi bisa mewujud melalaui berbagai bentuk. $\mathrm{Sa}$;ah satunya melalui pemilihan umum untuk menciptakan good governance. Setiap warga negara dalam pemilihan umum mempunyai satu hak pilih (suara) yang mewakili dirinya, yang dapat digunakan untuk mendukung seorang kandidat politik. Sedangkan pemilu sendiri merupakan sebuah arena yang mewadahi kontestasi aktor-aktor politik (termasuk para partai pengusungnya) untuk meraih kekuasaan di kursi pemerintahan.

Lebih jauh Menurut Herbert McClosky, menjelaskan keturutsertaan atau berperan dalam pemilu langsung maupun tidak langsung dan dilakukan dengan kerelaan adalah salah satu bentuk partisipasi politik. Melengkapi penjelasan McClosky, Samuel P. Huntington dan Joan M. Nelson memberi tambahan batasan yang diberikan McClosky menyoal partisipasi, diantaranta partisipasi mobilisasi dan partisipasi otonom. Wujud partisipasi yang dilakukan secara sadar, sukarela dan tanpa tekanan oleh Hutington dan Nelson disebut dengan partisipasi otonom. Sementara, jika 
kondisinya terbalik dimana partisipasi dilakukan dalam keadaan terpaksa bahkan tidak sadar disebut dengan partisipasi mobilisasi. Meski ciri keduanya kontras, namun demikian ia tetap disebut sebagai partisipasi. Atas dasar argumentasi inilah Huntington dan Nelson menyebut partisipasi bisa mewujud sebagai individu atau kolektif, terorganisasi atau spontan, mantap atau sporadis, damai atau kekerasan, legal atau ilegal, dan efektif atau tidak efektif (Damsar, 2013:180).

Hutington maupun Nelson menganggap Pernyataan McClosky dipahami sesuatu yang seharusnya terjadi. Sedangkan Huntington berpijak pada realita yang ada, dimana praktiknya tidak dapat dipungkiri terjadi. Sehingga keduanya menampakkan das solen maupun dass sein. Meski keduanya berbeda pendapat menyoal partisipasi dalam demokrasi, namun terdapat titik temu antar keduanya. Keduanya sepakat dengan batasan partisipasi politik dalam konteks proses pemilihan penguasa dan pembuatan kebijakan dalam ruang lingkup negara atau pemerintahan. Berangkat dari argumentasi kedua tokoh inilah topik penelitian akan dibahas dimana pemilu dalam kerangka konstelasi kekuasaan dan partisipasi masyarakat sebagai bagian dari warga suatu negara, dapat dianalisis menggunakan dasar pijakan teori yang telah diungkapkan para pakar tersebut.

Terdapat dua konsep penting dalam teori partisipasi yakni partisipasi (peranserta masyarakat) dan (arena kompetisi) politik. Secara umum, tingkat kelayakan sebuah sistem politik dan demokrasi dapat diukur dari seberapa tinggi keterlibatan publik dalam konstelasi politik pemerintahan seperti pemilihan umum (sebagai arena kompetisi).

Sejalan dengan Robert Dahl menjelaskan ada dua dimensi pokok dalam demokrasi, yaitu kontestasi dan partisipasi (Hakim, 2011:177). Gambaran ideal dari berhasilnya pemilihan umum adalah lahirnya pemerintahan yang demokratis dan memberi ruang pada tumbuhkembangnya civil society. Sementara menyangkut pemilihan umum, Dahl menjelaskan pemilihan umum dapat dikatakan demokratis jika memenuhi beberapa syarat mulai dari: (1)pemilu teratur, (2)rotasi kekuasaan, (3)rekrutmen terbuka/transparansi, dan (4)akuntabilitas publik (Liando, 2016:17).

\section{METODE PENELITIAN}

Sebagaimana lazimnya penelitian kualitatif, Sumber data dalam penelitian ini dibagi menjadi sumber data primer dan sumber data sekunder. Sumber data primer adalah data yang diperoleh langsung dari lapangan baik melalui observasi maupun melalui wawancara dengan pihak informan (Ghony \& Almansur, 2012:175). Sementara, data sekunder diperoleh melalui studi pustaka, baik buku, artikel maupun berita yang berkaitan dengan partisipasi masyarakat dalam pemilu serentak tahun 2019 di Kabupaten Buleleng. Informan penelitian terdiri dari informan kunci, informan utama dan informan tambahan (Sutinah \& Suyanto, 2013: 171). Informan kunci adalah mereka yang memiliki informasi pokok yang dibutuhkan dalam penelitian dalam hal 
ini adalah komisioner KPU Bali, dan Buleleng, informan utama sendiri adalah pihak yang memiliki keterlibatan dengan informan kunci atau terlibat secara aktif dalam isu penelitian. Pada konteks ini, informan kunci adalah pengamat politik, dan masyarakat Kabupaten Buleleng, serta informan tambahan yaitu pihak yang dapat memberikan informasi tetapi secara tidak langsung terlibat.

\section{HASIL DAN PEMBAHASAN}

Berdasarkan data yang dirilis KPU Bali jumlah pemilih pada pemilihan umum serentak 2019 berjumlah 3224 . 479 orang. Laki-laki 1.596. 740 sementara perempuan menyentuh angka1.623.799 orang. Dari total daftar pemilih tersebut, 20.543 adalah pemilih pemula (Mediaindonesia.com, 12/5/2019). Detailnya, daftar pemilih ini terdiri dari DPT sejumlah 3.130.288 (laki-laki 1.556. 427, perempuan 1.573.861), DPTB sejumlah 23.156 (11.631, perempuan 11.525), dan daftar pemilih khusus sejumlah 67.035 (laki-laki 28.788, perempuan sejumlah 38247). Dari jumlah total daftar pemilih tersebut, orang yang menggunakan hak suara hanya 2616.810 orang dari 12.384 jumlah TPS.

Jumlah pengguna hak suara di berbagai darah di Bali berbeda-beda. Secara lebih terperinci data rekapitulasi Komisi Pemilihan Umum Provinsi Bali mencatat, Kabupaten Jembrane 190.583 jiwa, Tabanan 325.867 jiwa, Badung 340.559 jiwa, Gianyar 336.298 orang, Klungkung 133.208 jiwa disusul Bangli dengan jumlah 164.013 jiwa, Karangasem 304.984 Jiwa, Buleleng 439.787 jiwa dan Kota Denpasar 381.511 jiwa. Sedangkan untuk Daftar Pemilih Tetap (DPT) Kabupaten Jembrane 235.284, Tabanan 366.150, Badung 384.609, Gianyar 370.030, Klungkung 160.080, Bangli 187.371, Karangasem 380.195, Buleleng 582.437 dan Kota Denpasar 464.132. Dengan demikian jumlah total DPT dari semua kabupaten/kota di Bali mencapai 3.130.288 jiwa (KPU.go.id).

Tabel 1. Daftar Pemilih Tetap dan TPS Kabupaten Kota di Bali Tahun 2019

\begin{tabular}{|c|c|c|c|c|c|c|c|}
\hline \multirow{2}{*}{ No. } & \multirow{2}{*}{$\begin{array}{c}\text { Nama } \\
\text { Kabupaten/Kota }\end{array}$} & \multirow{2}{*}{$\begin{array}{l}\text { Jumlah } \\
\text { Kec }\end{array}$} & \multirow{2}{*}{$\begin{array}{l}\text { Jumlah } \\
\text { Kel/Desa }\end{array}$} & \multirow{2}{*}{$\begin{array}{l}\text { Jumlah } \\
\text { TPS }\end{array}$} & \multicolumn{3}{|c|}{ Jumlah Pemilih } \\
\hline & & & & & L & $\mathrm{P}$ & $L+P$ \\
\hline 1 & DENPASAR & 4 & 43 & 1,737 & 229,500 & 234,632 & 464,132 \\
\hline 2 & BADUNG & 6 & 62 & 1,411 & 189,250 & 195,359 & 384,609 \\
\hline 3 & TABANAN & 10 & 133 & 1,544 & 180,029 & 186,121 & 366,150 \\
\hline 4 & JEMBRANA & 5 & 51 & 876 & 116,209 & 119,075 & 235,284 \\
\hline 5 & BULELENG & 9 & 148 & 2,146 & 292,171 & 290,266 & 582,437 \\
\hline 6 & BANGLI & 4 & 72 & 843 & 94,037 & 93,334 & 187,371 \\
\hline 7 & KARANGASEM & 8 & 78 & 1,706 & 192,319 & 187,876 & 380,195 \\
\hline 8 & KLUNGKUNG & 4 & 59 & 619 & 79,013 & 81,067 & 160,080 \\
\hline 9 & GIANYAR & 7 & 70 & 1,502 & 183,899 & 186,131 & 370,030 \\
\hline TOTAL & & 57 & 716 & 12384 & $1,556,427$ & $1,573,861$ & $3,130,288$ \\
\hline
\end{tabular}

Sumber: KPU Provinsi Bali 
Berdasarkan hasil rekapitulasi KPU Kabupaten Buleleng menunjukkan Hasil rekapitulasi untuk kursi DPRD Kabupaten dari enam daerah pemilihan (dapil) Kabupaten Buleleng (Dapil I Kecamatan Buleleng, Dapil II kecamatan Sawan, Dapil III Kecamatan Kubutambahan dan Tejakula, Dapil IV Kecamatan Seririt dan Gerokgak, Dapil V Kecamatan Banjar dan Busungbiu), masing-masing mendapatkan suara, PKB 13.948, Gerindra 38.166, PDIP 157.617, Golkar 61.995, Nasdem 37.535, Garuda 1.244 Berkarya 6.474, Perindo 16.269, PPP 1.846, PSI 3.500, PAN 5.083, Hanura 33.002, Demokrat 36.816 dan PBB 199.Suara hasil pemilu itu mengacu pada pemilih sebanyak 596.457 dengan suara sah sebanyak 414.066 dan tidak sah 24.995.

Berbeda dengan hasil rekapitulasi suara dalam perebutan kursi DPRD Provinsi Bali dari Dapil 5 Kabupaten Buleleng menunjukkan, dari 439.267 pemilih suara sah tercatat 401.818 dan tidak sah 37.449 suara. Rinciannya,PKB 15.190, Gerindra 16.025, PDIP 190.929, Golkar 54.872, Nasdem 36.711, Garuda 1.466, Berkarya 5.623, PKS 1.060, Perindo 14.739, PPP 1.897, PSI 3.600, PAN 9.567, Hanura 16.665, Demokrat 32.900, PBB 197 dan PKPI 377.

Pileg DPR-RI, suara sah tercatat 384.400 dan 54.926 suara tidak sah dari total pemilih 439.326.Suara yang diraih partai maupun calon yakni PKB 13.005, Gerindra 15.747, PDIP 164.565, Golkar 78.044, Nasdem 19.880, Garuda 1.451, Berkarya 10.509, PKS 6.696, Perindo 8.461, PPP 2.166, PSI 6.177, PAN 3.359, Hanura 15.511, Demokrat 38.166, PBB 413 dan PKPI 250.

Sementara rekapitulasi Pemilihan DPD-RI, dari 22 calon senator tercatat mendapatkan suara tertinggi diperoleh Dr. Shri I.G.N Arya Wedakarna MWS, S.E (M.TRU).,M.Si., dengan 96.179 suara,diurutan kedua mantan Gubernur Bali, Drs. Made Mangku Pastika, M.M., dengan 92.777 suara, menyusul Gede Lanang Darma Wiweka dengan 27.123 dan urutan ke empat di raih H.Bambang Santoso dengan perolehan 24.932 suara.Hasil rekapitulasi itu juga mencatat jumlah pemilih sebanyak 439.327 dengan suara sah 386.053 dan 53.274 suara tidak sah.

Pada penetapan rekapitulasi Pilpres 2019 untuk Kabupaten Buleleng,dari sebanyak 429.732 suara sah dan suara tidak sah sebanyak 46.161 suara.Pasangan 01, Ir H. Joko Widodo dan Prof. Dr. (H.C) KH. Ma'ruf Amin, memperoleh 383.571 suara. Dan Pasangan 02, H. Prabowo Subianto dan H. Sandiaga Salahuddin Uno mendapatkan 46.161 suara.

Secara matematis, tingkat partisipasi masyarakat Buleleng menyentuh jumlah partisipasi pemilih menembus angka 70 persen tepatnya pada angka 73,71 persen, sementara angka partisipasi provinsi Bali pada pemilu serentak tahun 2019 menyentuh angka $81,25 \%$. Selama ini tingkat partisipasi pada tiap ajang pemilihan di Kabupaten Buleleng, selalu di bawah angka 70 persen. Jika dibandingkan dengan pemilu 2014 lalu, angka partisipasi pemilih hanya 62,05 persen. Sementara pada Pilgub Bali 2018, angka partisipasi hanya 58,06 persen. 
Partisipasi terendah justru pada Pilbup Buleleng 2017, yang hanya diikuti 54 persen pemilih. Merujuk data dalam sertifikat rekapitulasi hasil penghitungan perolehan suara capres-cawapres, yang diterbitkan KPU Buleleng pada pemilu serentak tahun 2019, ada 596.589 orang pemilih di Buleleng. Pemilih itu terdiri dari pemilih dalam Daftar Pemilih Tetap (DPT) sebanyak 582.437 orang (P: 290.266, L: 292171), pemilih dalam Daftar Pemilih Tambahan (DPTb) sebanyak 1.557 orang (P: 684 L: 873), serta pemilih dalam Daftar Pemilih Khusus (DPK) sebanyak 12.595 orang (L: 5515 P: 7080). Sementara jumlah pengguna hak pilih mencapai 439.787 orang. Terdiri dari 426.005 orang yang tercantum dalam DPT, 1.215 orang dalam DPTb, dan 12.567 orang dalam DPK. Jika jumlah pemilih dikurangi jumlah pengguna hak pilih, maka ditemukan angka 156.802 orang yang tak menggunakan hak pilih, atau sekitar 26,28 persen dari keseluruhan jumlah pemilih terdaftar. Dengan kata lain ada 156.802 jiwa yang golput atau 26,28 persen. Angka 26,28 persen ini tidak hanya disebabkan karena tidak mendapatkan kartu undangan sebagai pemilih namun juga disebabkan oleh banyaknya kelompok orang yang tidak berminat pada politik sama sekali atai disebut dengan golongan apolitis (Damsar, 2013:183-184). Meminjam tipologi partisipasi politik David Roth dan Frank Wilson tipe apolitis ini berada pada posisi paling bawah dalam segitiga partisipasi politik dan pada umumnya jumlahnya cukup besar.

Secara lebih detail perhitungan pengguna hak pilih pada masing-masing pemilihan mulai presiden, DPR, DPRD dan DPD dalam pemilu serentak tahun 2019 di Kabupaten Buleleng jumlahnya berpariatif. Pada pemilihan presiden jumlah pengguna hak suara sejumlah 439. 787 (L: 226.432 P: 213.355), pada pemilihan DPRD jumlah pengguna hak pilih sejumlah 439.267 (L: 226.214 P: 213053), pada pemilihan DPRI jumlah pengguna hak suara berjumlah 439.327 (L: 226.228 P: 213.099), pada pemilihan DPD RI jumlah pengguna hak suara berjumlah 439.327 (L: 298559 P: 298.030).

Tingginya angka partisipasi masyarakat Buleleng pada pemilu serentak tahun 2019 ini disebabkan oleh masifnya informasi di media baik cetak, siar maupun online. Pemberitaan menyangkut pemilu serentak hampir setiap hari muncul dalam setiap stasiun TV di Indonesia. Tidak hanya di TV pemberitaan soal pemilu juga muncul di berbagai platform media sosial. Hal ini secara tidak langsung menjadikan public memiliki ketertarikan yang cukup untuk terlibat berpartisipasi dalam pemilu. Hal ini sejalan dengan apa yang dijelaskan Damsar (2013) bahwa, media memiliki peran sangat penting sebagai pilar demokrasi. Tingginya angka partisipasi masyarakat Buleleng juga tidak terlepas dari upaya yang dilakukan oleh penyelenggara pemilu Kabupaten Buleleng. Selain menggandeng Relawan Demokrasi dari berbagai basis atau elemen masyarakat, pelaksananaan sosialisasi juga dilakukan melalui berbagai kegiatan, salah satunya melalui Pemilu Run di Lapangan Taman Kota Ngurah Rai Singaraja. Cara-cara semcam ini menjadikan public tidak jenuh mendengar sosialisasi konvensional seperti sebelumnya yang biasanya dilakukan di gedung-gedung dan mendengarkan penyelenggara pemilu menyampaikan materi. Tingginya angka partisipasi masyarakat Buleleng pada pemilu sertentak tahun 2019 jika meminjam dua 
konsep partisipasi politik Samuel Hutington, tergolong ke dalam partisipasi otonom, yakni wujud partisipasi yang dilakukan secara sadar, sukarela dan tanpa tekanan karena keterlibatan publik didasarkan pada kesadaran penuh untuk memberikan hak suara dan menentukan Indonesia lima tahun kedepan (Damsar, 2013:180).

\section{KESIMPULAN}

Pengguna hak pilih di Kabupaten Buleleng sejumlah 439.787 jiwa, Secara prosentase, partisipasi masyarakat dalam pemilu serentak di Kabupaten Buleleng sejumlah 73,91\%. Pada pemilu serentak tahun 2019, ada 596.589 orang pemilih di Buleleng. Sementara jumlah pengguna hak pilih mencapai 439.787 orang yang terbagi ke dalam 2.146 TPS. Tingginya angka partisipasi disebabkan oleh keberhasilan sosialisasi KPU, informasi yang masif di media baik media cetak, siar, maupun online. Dari semua kabupaten yang ada di Bali, Buleleng tercatat sebagai salah satu kabupaten dengan tingkat suara tidak sah cukup tinggi yaitu sejumlah 37.449 sedangkan suara sah sejumlah 401.818. Tingginya angka suara tidak sah disebabkan persoalan teknis yang menyulitkan terutama bagi pemilih lanjut usia. Di Kabupaten Buleleng sendiri tingkat pemilih lanjut usia dibandingkan kabupaten lain sangatlah tinggi menyentuh angka 92.101 jiwa dengan perincian laki-laki sejumlah 42.170 jiwa, perempuan sejumlah 49.931 jiwa.

\section{REFERENSI}

Alvantara, H.Kenzou.2017. Buku Babon Sejarah Dunia. Yogyakarta. Briliant Book. Anthony, Giddens. 2009. Melampaui EkStrim Kiri dan Kanan: Masa Depan Politik Radikal. Yogyakarta. Pustaka Pelajar

Damsar.2013. Pengantar Sosiologi Politik. Jakarta. Pustaka Pelajar

Fuad Hasan. 1986. Apologia: Pidato Socrates yang Diabadikan Plato. Jakarta: BulanBintang

Fukuyama, Francis. 2004. The End of History and The Last Man. Jakarta Qalam

Ghony, M. \& Almanshur, F. 2012. Metode Penelitian Kualitatif. Jogjakarta: Ar-Ruzz

Medi

Hakim, Abdul Aziz.2011. Negara Hukum dan Demokrasi. Yogyakarta. Pustaka Pelajar Huntington, Samuel. 2012. Benturan antar Peradaban dan Masa Depan Politik Dunia. Jakarta. Qalam.

Kartono, Kartini. (1986). Pengantar Metodologi Riset Sosial. Bandung: AlumniBandung.

Marijan, Kacung. 2012. Sistem Politik Indonesia: Konsolidasi Demokrasi Pasca Orde Baru. Jakarta. Kencana Prenada Media 
Samidjo.2001. Ilmu Negara. Bandung: CV Armico

Schumpeter, A.Joseph. 2013. Capitalism, Socialism dan Demokrcracy. Yogyakarta. Pustaka Pelajar

Jurnal:

Liando, Daud. Pemilu dan Partisipasi Masyarakat (Studi Pada Pemilihan Anggota Legislatif dan Pemilihan Presiden dan Calon Wakil Presiden di Kabupaten Minahasa Tahun 2014), Jurnal LPPM Bidang EkoSosBudKum, Vol.3,No.2, Oktober 2016. 